\title{
A CRITICAL DISCOURSE ANALYSIS OF LANGUAGE USE ON FACEBOOK: A STUDY OF PREMIUM TIMES NEWS HEADLINES
}

\author{
Rita Bossan $\mathrm{PhD}$ \\ Department of English and Drama \\ Kaduna State University \\ gimbiyabossan@gmail.com \\ $+2348025812599$ \\ Gideon Abioye Oyedeji \\ General Studies Department \\ Air Force Institute of Technology \\ dejigideon@gmail.com \\ $+2347065993288$
}

\begin{abstract}
Attaining national unity and cohesion is a function of deliberate strategic plans of different facets of human endeavour in a nation. The language front has important role to play in fostering national unity and cohesion in any country. The Nigeria and Africa situation is not an exception. The chaos and rivalry that have become an intrinsic experience for us in Nigeria and in fact, Africa is partly a function of careless and unchecked language use in the social media. This paper, therefore, explores the use and misuse of language on social media. The study examines the comments of Facebook users to online news headlines posted on Premium Times Facebook handle. A corpus of a week screenshot samples of these comments are collected out of which nine (9) were purposively selected for the analysis. These nine (9) data are grouped into five (5) texts. The selected data were analysed using Dell Hymes' Ethnography of Speaking complemented by Theo van Leeuwen's Identities and Subjectivity Model of Critical Discourse Analysis (CDA). The paper uses the SPEAKING acronym as the theoretical insight and discussion was based on the postulations of the CDA model adopted. The study found that the responses from readers are mostly tilting towards their individual affiliations. Also, instances of arguments and rebuttals by readers reflect a situation where the polarity tilts in bidirectional positive in-group - "us" and negative out-group - "them" among the different affiliations the users represent. The study further found that copious use of vulgar expressions pervades the comments of readers. This study therefore concludes that such use of language cannot help Nigeria and Africa in its quest for unity. The study recommends that media literacy be taught in schools in order to entrench civility in the discussions of people on social media.
\end{abstract}

Keywords: Language use, National Unity, Social Media, Ideologies, Identities

\section{INTRODUCTION}

Language is a unique gift from God. Language covers all aspects of our daily thoughts and endeavours. It is one unique feature that differentiates human beings from other creatures on earth. Several attempts have been made to define and describe language by scholars, Crystal and Davy (1987), describe language as the conventional and systematic use of signs, sounds or written symbols in a society, for communicative purposes and human expression. Good language is that which is suitable and adaptive in a given communicative situation (communicative competence). It is that which assists in achieving a meeting of minds with listeners and does not detract from the thought. Good language is language that serves to unify the speaker, the message and audience. It is language which gets the derived effect with the least friction and difficulty for the user. Chilton and Schaffner (1997), is of the opinion that language is the universal capacity of humans in all societies to communicate, a succinct description which is intriguing and at the same time very much relevant to this quest is given by Adedimeji (2010, p. 3) which says that "language mainly serves to form (or deform), 
inform, reform and transform man and his society all of which are harmonious with the goal of politics, making the two concepts symbiotic".

Language plays a prominent role in unifying people. Ashcroft (2001) opines that language is a model through which a hierarchical structure of power is perpetuated and the medium through which conceptions of truth order and reality becomes established. Language is a tool for constructing social realities. Halliday (2004) in his classical treatise opines that language plays three functions that are intertwined which are captured as Ideational Meta-function. The author believes that people's material world, world of inner consciousness and their world of symbolisation are constructed and reflected by the use of language. The way language functions in the social media reflect how language has shaped people's social realities, and this has entrenched disunity over time. It is true that the problem of disunity is historical in Nigeria; cautious use of language is potent in curbing the escalation of verbal insults that pervades social media. Van Dijk, (1993, 1998, 2008b) discussed the power of language and the way it results in particular social cognition. He describes social cognition as how the media influence people's thought.

The Facebook platform has witnessed pockets of verbal exchanges over the past decades. Users haul insults at one another at the slightest provocation. Because of the absence of laws which are used to regulate the use of this platform, the misuse of language has become common place on Facebook. This study, therefore, explores the use and abuse of language on the Facebook environment with a view to evaluate the use of and misuse of language by Facebook users and the ideologies that underpin such usages. This study hopes to reveal the extent to which Nigerians have slumped into chauvinistic attitudes which if not nipped at the bud, a state of anarchy will be inevitable. The reasons the government officials must, as a matter of urgency, enact and implement cyber restriction laws and to introduce media literacy in schools are because Facebook is open to all and sundry.

\section{LANGUAGE USE AND MISUSE}

Abuse of language is universally used to describe any communication that denigrates a particular person or a group on the basis of race, colour, ethnicity, gender, disability, sexual orientation, nationality, religion, or other characteristic. It can be in the form of speech, gesture, conduct, writing, or display. Dangerous speech on social media in a country like Nigeria can be volatile and lead to conflict. In this case, posts by peddlers of hate and dangerous speeches can be assumed to embody legitimacy and authority. Secondly, social media have a wide and instantaneous reach which makes it easy tool for mobilisation. One of the main purposes of peddling hate speech is to mobilise people and incite communities to carry out violence. It has incessantly proved difficult by regulatory bodies to tame the use of hate speeches on social media probably because some of the sponsors of the hate speech peddlers are politicians who are in government or seeking political relevance or candidates contesting elections. In fact, some broadcast media prefer to broadcast hateful contents because it is profitable and damn the fine that is usually less than the much they mate from such broadcast. This has flowed down into the masses who use language as a willing tool to legitimise hegemony.

\section{LANGUAGE AND THE MEDIA}

Language use in the media as a tool for communication is deployed in various ways and it is quite distinct from the use of language in other spheres. Crystal and Davy (1969) opine that "everything that happens to be printed in a newspaper or written by a journalist is not going 
to be linguistically homogenous". They also claim that there is no reason to expect such "homogeneity" because meaning of newspaper contents does not reside in the contents rather the meaning(s) of media contents reside in the reader's worldview. The use of language in the media to develop content needs to be carefully selected out of competing forms so as to communicate civil meanings.

According to Taiwo (2004), something to keep in mind when reading newspaper articles is bias. Newspaper contents are guided by specified editorial policies and these policies are birthed by the ideological affiliations the producers represent. However, bias is necessarily political. The bias could be ethnic, economic, environmental and even religious. Many journalists have been accused of being bias for not representing a balanced viewpoint in a report.

In the 21 st century, the media possess subtle power to present and represent issues and people in a coded and symbolic way through the use of language, and image mediated communication. According to Ogungbe (2008), there is interplay of politics in the ways people, regions, groups, events, policies and other socio-political issues are represented in the media. He further notes that media representation is ideological, political as well as powerful because it has real effects on people's lives, rights, thoughts and actions in the society. The media to a large extent shapes peoples' view of the world around them.

\section{ETHNOGRAPHY OF SPEAKING}

The ethnography of communication (EOC) which eventually metamorphosed into ethnography of speaking, deals with the analysis of utterances of communication based on the cultural and situational context, beliefs and practices of the interactants in a speech community. This method of language analysis draws insight from the anthropology of ethnography. It explores the varying appurtenances of communication and the varying goals of communicative events. This approach to discourse analysis, looks beyond the formal properties of communication, it delves into investigating other communicative nuances including societal conventions that govern discourse production and use.

Dell Hymes came up with a model of framework for analysing speech event in their contextual speech community. He proposed the SPEAKING model. The model comprises some cogent elements for analysing communicative speech events. The proponent of this discourse analysis approach believes that for a speech event to take place and be taken as a discourse there are key elements that must be present which include: message form, message content, speaker, scene, purpose, addressor, audience, channels, norms of interaction and interpretation, genres, and key. These are elements are further categorised into the SPEAKING acronym.

- $\mathbf{S}$ stands for Setting and scene: This is where the speech event took place. It encapsulates the time and place of the communicative event.

- P stands for Participants who took part in the discussion. This includes the addresser, addressee and even the eavesdropper.

- E stands for ends: This has to do with the purpose of the communication. What outcome is expected from the listener(s).

- A stands for act sequence: In speech situation, there is always a sequence - direction of communication. Every speech even has a sequence and the speech acts that make up the communication. 
- K stands for $\boldsymbol{k e y}$ : This involves the manner, i.e. how the message is communicated; is it serious or just a joke? Is it sincere or it is a mere banter?

- I stands for instrumentalities: This is how the message gets to the hearers. It deals with the channel of communication. Messages are communicated via different means. It could be written, verbal, physiognomy, songs, drums, etc. This also involves the operational language used by the discussants.

- $\mathbf{N}$ stands for norms of interaction: Language use is rule govern, so, the norms of interaction involves both the knowledge of the communicative competence and performance competence of the operational language within a speech communication i.e. the knowledge of what is acceptable and the taboos of the speech community.

- G stands for genres: This involves the form for message which could be formal or informal, casual or non-casual, interview or editorial, cartoons or comic strips, poetic or prosaic, etc.

\section{CRITICAL DISCOURSE ANALYSIS}

Critical Discourse Analysis (CDA) is a multidimensional theory which focuses on unearthing the power relations and dominance in media discourse - texts and visuals. It focuses on describing, interpreting and explaining language variation, communicative interaction with special attention on issues of social literacy and power (Wodak 2007). According to van Dijk (2004), CDA focuses on how power, hegemonic tendencies, inequality is be uncovered in discourses. Fairclough (1999, pp. 132-3), defines CDA as method of analysing discourse in a systematic way as to capture the description of the cryptic relationship between the text and society in relation to how "powers" are ideologically enacted.

Discourse has so many definitions formulated from various theoretical and disciplinary standards. Since discourse is a normative term, it can be defined in varying ways with each definition elucidating a part of its scope. Within a Critical Discourse Analysis purview, discourse is seen as the use of language resonating from a social practice. Hence, Atkins, (2002, cited in Mirzaee and Hamdi, 2012, p. 184) pinpoints that "paying attention to this concept, language cannot be regarded as neutral, since it is caught up in political, social, racial, economic, religious, and cultural formations". Fairclough (2013) agrees with other scholar's view of discourse and further incorporated semiotic elements and printed disquisitions and nonverbal communication as forms of discourse. However, he refers to language as a discourse, which is an intrinsic socio-cultural practice. This strongly suggests that language has impetus to propel action and it is capable of thought and character transformation.

The study adopts Theo van Leeuwen's (2008) Identities and subjectivity model of Critical Discourse Analysis to unearth the different ideological identities and subjectivities in the selected data.

\section{THEO VAN LEEUWEN'S IDENTITIES AND SUBJECTIVITY MODEL}

Leeuwen's (2008) avers that the society is influenced by the policies and engagements of the powers that be. He outlines the core ways in which people are represented through discourse. $\mathrm{He}$ opines that, "CDA is the impact of power structures on the production and/or reproduction of knowledge and its effect on identity and subjectivity of the members of the community. Indeed, this is language and discourse in relation with production, reproduction, dissemination, and interpretation of knowledge in line with researchers' arrangement". Leeuwen's (2008) model outlines the following: 
1. Exclusion: This is the total removal of both the participants and the activities in the contextualisation of the social practice.

a. Suppression: Here, the participants are not mentioned but are referred to so as to provide context for the utterance.

b. Backgrounding: The social actors are not obviously mentioned. They only pop up later in another part of the discourse

2. Inclusion: This occurs when the actors are mentioned as part of the communicative event.

a. Activisation and passivisation: The roles of the social actors are either shown to be in active voice or passive voice. Where this happens, it is copious of an ideological meaning which the author wishes to communicate.

b. Genericisation: This happens when the participants are presented as a class though a complex linguistic arrangement.

c. Specification: This entails giving the full identity of participants so that they can easily be identified.

d. Individualisation and Assimilation: Participants are represented as individuals and other are represented as a member of a group respectively.

e. Indetermination: This occurs when social actors cannot both be identified as individuals or as members of a group.

f. Determination: The actor can be identified in a very clear manner.

g. Nomination and Categorisation: Nomination shows the representation of people in terms of their individuality, and peculiar identity, whereas categorisation shows the roles of participants and their relationship with other participants.

h. Functionalisation and Identification: While functionalisation deals with the activities that a participant handles, the identification show what the participant is.

3. Impersonalised Social Actors: This deals with actors that are not humans. This is therefore achieved though abstraction and objectivation.

a. Abstraction: It is a situation where participants are presented by qualities which are given to them.

b. Objectivation: Here, participants are represented by making reference to objects that have affinities with them.

\section{METHODOLOGY}

This study is a critical discourse analysis of language use and misuse on social media, specifically Facebook. The paper explores the use of language as a tool for engendering national unity and the opposite because when there is no national cohesion, achieving development will be illusory. The data for the study are gotten from the Premium Times Facebook handle where news headlines are posted. A total of 50 of these headlines are screen shot and a total of nine are purposively selected for the study. The data selected covered just a week - between 10th and 18th February, 2020. Theoretical insights are gotten from Dell Hymes' Ethnography of Speaking and Theo van Leeuwen's Identities and Subjectivity Model of Critical Discourse Analysis to analyse a total of nine readers' comment of Facebook news headlines. The selection is done using purposive sampling technique and the analysis is organised in text-by-text format. The tabular analysis is done using Ethnography of Speaking mnemonics and the discussion is done using Subjectivity and Identities model of Critical Discourse Analysis. 


\section{DATA PRESENTATION AND ANALYSIS}

\section{Text 1}

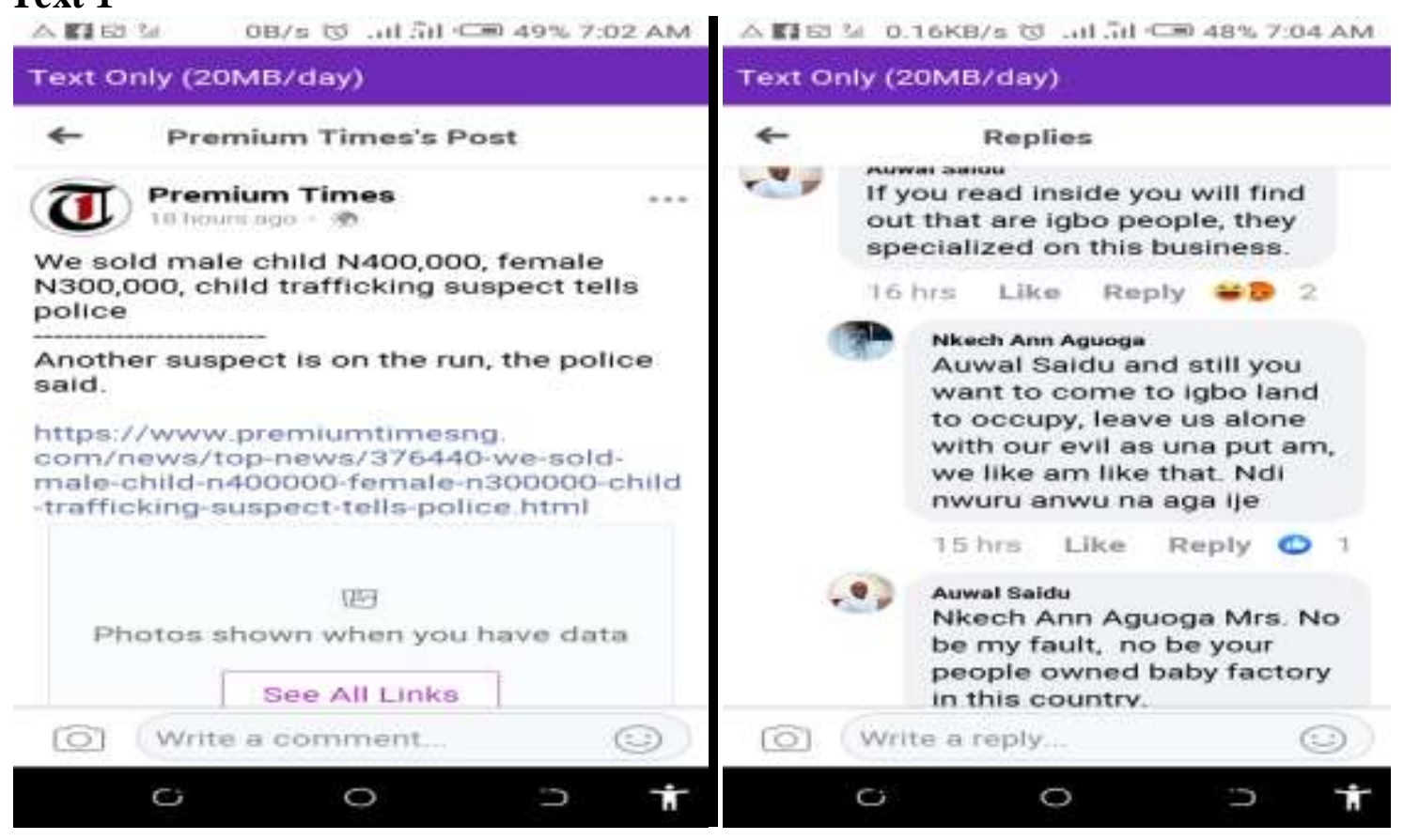

\begin{tabular}{|l|l|}
\hline Setting & Premium Times Newspaper on Facebook \\
\hline Participants & Auwal Saidu and Nkech Ann Aguoga \\
\hline Ends & $\begin{array}{l}\text { The Interactants get at each other because of their ethnic difference. The first } \\
\text { user in commenting on the news headline smears the image of the Igbos and } \\
\text { another user from the Igbo extraction responded in a bid to show that the Igbos } \\
\text { are okay. }\end{array}$ \\
\hline Acts Sequence & $\begin{array}{l}\text { The headline is a declarative act stating the situation in the country. The } \\
\text { headline is followed by an expressive act accusing a section of the country and } \\
\text { the comment is rebutted by an expressive act of insult. }\end{array}$ \\
\hline Key & $\begin{array}{l}\text { The manner of presentation of these comments indicates the enmity between } \\
\text { the two divide in the country. }\end{array}$ \\
\hline Instruments & $\begin{array}{l}\text { Typing was adopted by the users and they communicated in both English and } \\
\text { Igbo languages. The second user used a proverb in responding to the first user's } \\
\text { comment. This proverb is used to demean the person and ethnic affiliation of } \\
\text { the first user. }\end{array}$ \\
\hline $\begin{array}{l}\text { Norm } \\
\text { Interaction }\end{array}$ & $\begin{array}{l}\text { Facebook provides platform for turn taking in post online. It's a kind of } \\
\text { synchronous communication. }\end{array}$ \\
\hline Genre & \begin{tabular}{l} 
Its Facebook post. Short sentence and casual conversation(casual conversation) \\
\hline
\end{tabular}
\end{tabular}

\section{DISCUSSION}

The comments above exemplify the subjective idea some people hold about the identity of Igbos. This subjective idea however, suppresses and misrepresents this ethnic group. It is vivid that this kind of ideology is already engraved in the heart of the first discussant above. Furthermore, the bias it express polarises a negative out-group discourse which criminalises others. It is however of grave consequence on the social fiber of the nation. It clearly indicates that Nigerians are yet to accept and tolerate one another. The specification fully identified the discussants hence we can contextualise these ideologies. The discussants both 
represent a group which they are out to protect while decimating the other group. Again, this kind of polarity exists copiously on social media. It indicates a pitiable situation that has made the coexistence of Nigerians fragile.

At the level of abstraction, the first comment above criminalises the entire Igbo race. It is a truism that every ethnic nationality in Nigeria always has the black sheep and we cannot criminalise the entire race on the basis of the few bad eggs. This kind of over generalisation cannot bring the kind of unity that we crave for.

\section{Text 2}

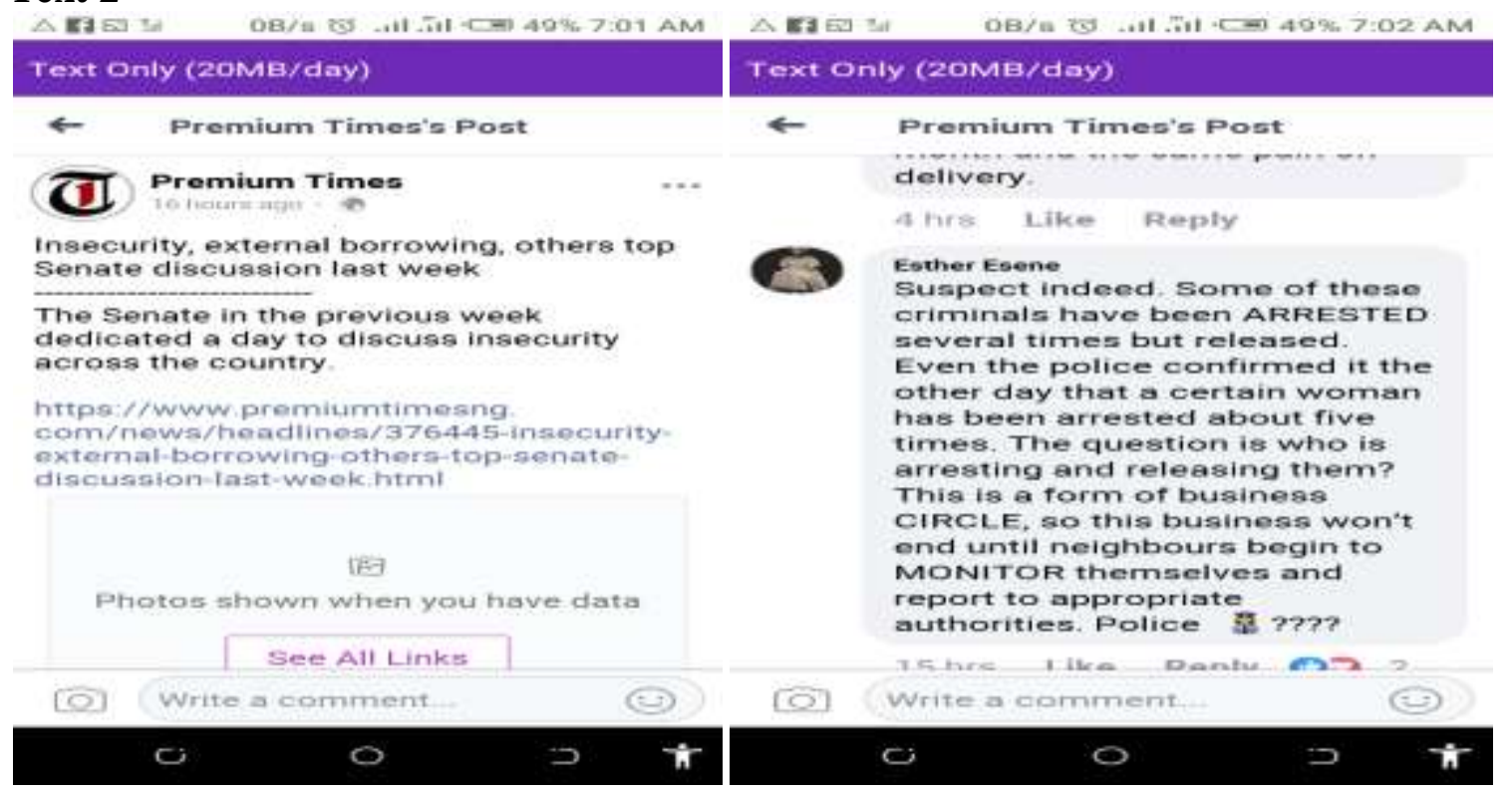

\begin{tabular}{|l|l|}
\hline Setting & Premium Times Newspaper on Facebook \\
\hline Participants & Esther Esene \\
\hline Ends & $\begin{array}{l}\text { The participants reacts to the claim in the news by asking thought provoking } \\
\text { question about how arrests are made and little or nothing is heard about the } \\
\text { arrest. This has been consistent in the nation and it has made many lose } \\
\text { confidence in the Nigerian Police. In fact, the comment exposes how the whole } \\
\text { situation has become business. }\end{array}$ \\
\hline Acts Sequence & $\begin{array}{l}\text { The news headline performs the illocutionary act of informing the readers of } \\
\text { the Senate engagement on security in the week. This act is followed by the } \\
\text { illocutionary act of exposing how security in the Nigerian police has become } \\
\text { business. Also, the comment calls on the Nigerian populace to take the bull by } \\
\text { the horn. }\end{array}$ \\
\hline Key & $\begin{array}{l}\text { The tone of the comment indicates that the Nigerian Police has failed and can } \\
\text { no longer be trusted. }\end{array}$ \\
\hline Instruments & $\begin{array}{l}\text { English has been used to communicate her thought. More importantly, the } \\
\text { graphological import of the last expression is worthy of note. The use of } \\
\text { question mark after "police" communicates meaning beyond letters. It } \\
\text { questions the credibility of Police in Nigeria. }\end{array}$ \\
\hline $\begin{array}{l}\text { Norm } \\
\text { of }\end{array}$ & $\begin{array}{l}\text { Again, the news platforms online allows for synchronous discourse and turn- } \\
\text { taking by Facebook users }\end{array}$ \\
\hline Genre & $\begin{array}{l}\text { It is a short Facebook post. Most of the discourse engagements by Facebook } \\
\text { users are short, precise and cryptic posts which communicate clear thought on } \\
\text { the headlines. }\end{array}$ \\
\hline
\end{tabular}


Volume 1 Number 1 Maiden Issue

\section{DISCUSSION}

This comment expresses an ideology that negates her personal worldview. It expresses a bias based on what she believed to be the standard practice in fighting crimes. The comment looks innocuous overtly. Ideologies, no doubt, are subjective; however criminalising crime suspects already polarizes the discourse based on negative out-group. Again, the comment also expresses a negative ideology against the Nigerian police. It is against the law to indict a person without evidence. This comment has already indicted the police of releasing criminal suspects. This is indicated by the graphological imprint in the comment. The use of question marks together with a police emoji supports this assertion. Again, reaching a sweeping conclusion on the police is ideologically warped. It is not all police officers that are bad. There are a number of fantastically upright and honest police officers. Therefore, this comment expressed a negative ideology on the police.

he stylistic import of two words used in the comments is worthy of note. "CIRCLE" and "MONITOR". The user used these words to emphasize certain aspect of meaning. First, when typing, using capital letters indicate shouting. Beyond shouting, the use of these words communicates cryptic ideological meanings. "CIRCLE" is used to further portray the police in a negative light while "MONITOR" is used to call the attention of the people to take the bull by the horn in the matter of security.

\section{Text 3}

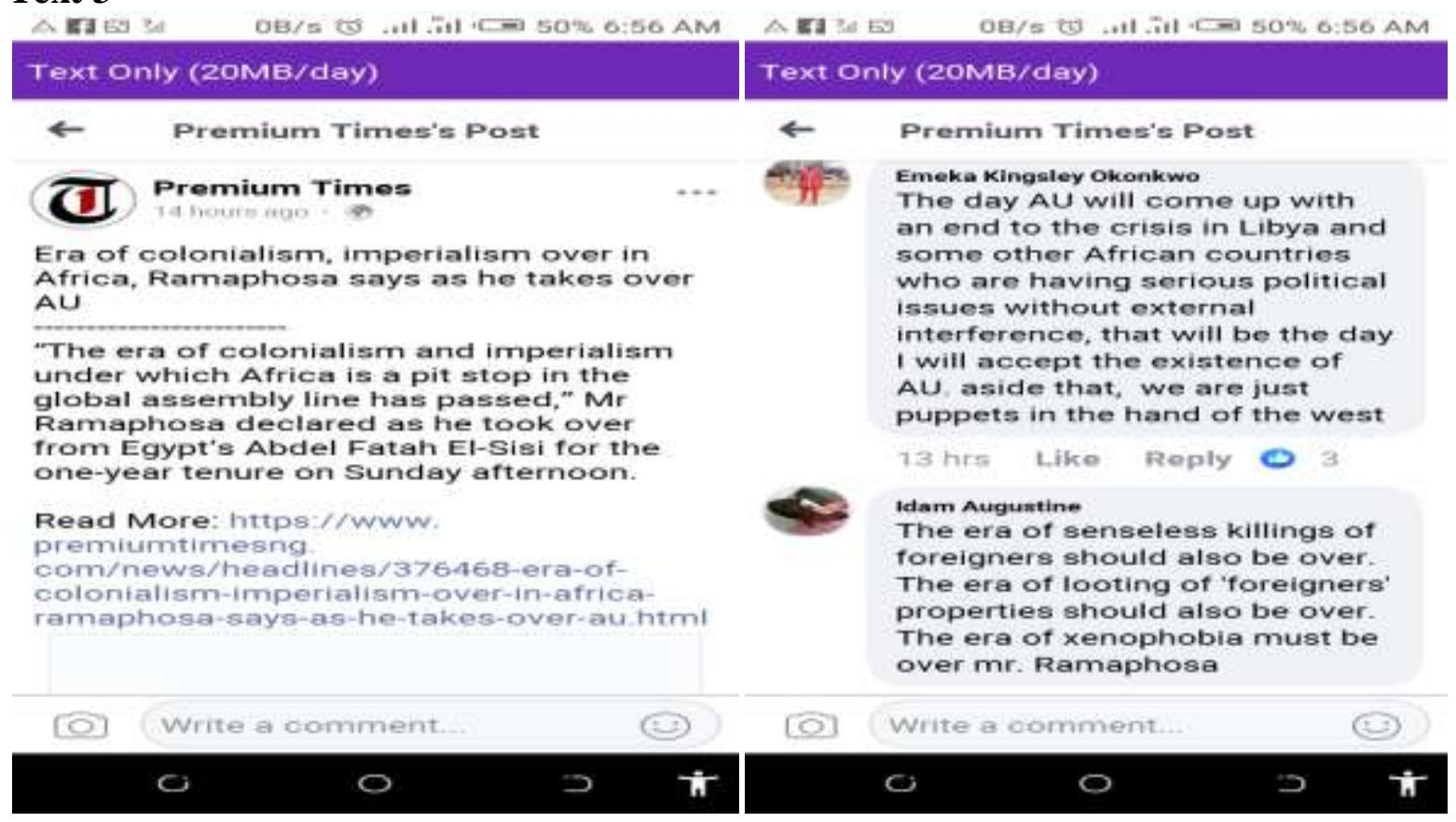




\begin{tabular}{|l|l|}
\hline Setting & Premium Times Newspaper on Facebook \\
\hline Participants & Emeka Kingsley Okonkwo and Idam Augustine \\
\hline Acts Sequence & $\begin{array}{l}\text { The comments are deployed to indict the west of continuous colonisation and } \\
\text { hegemony, and to challenge the South African President, Cyril Ramaphosa to } \\
\text { end the xenophobic attacks in South Africa. }\end{array}$ \\
$\begin{array}{l}\text { The illocutionary act of indictment of the west of continuous colonisation in } \\
\text { Okonkwo charged the South African President on the way out of the security } \\
\text { quagmires in Africa. The comment by Idam Augustine shows indirectly a non- } \\
\text { acceptance of the person of Cyril Ramaphosa especially that he was not able to } \\
\text { stem the tide of xenophobia in South Africa that many Nigerians had to return } \\
\text { to Nigeria because of these attacks. Through the comment, the user seems to be } \\
\text { telling Cyril Ramaphosa to put his house in order before talking about other } \\
\text { external forces. }\end{array}$ \\
\hline Key & $\begin{array}{l}\text { The tone of the comments indicates that the issue needs urgent action as the } \\
\text { continuous dominance of Africa by the west is uncalled for. }\end{array}$ \\
\hline Instruments & The comments are posted in simple English. \\
\hline $\begin{array}{l}\text { Norm } \\
\text { Interaction }\end{array}$ & Turn taking is evident in the comment \\
\hline Genre & The comments are typical samples of short posts. \\
\hline
\end{tabular}

\section{DISCUSSION}

Typically, Africa is on the trajectory of evolving a peaceful continent. Peace in Africa cannot be achieved in the atmosphere of suspicion and opposition. In a situation where Africans are afraid of fellow Africans, peace and progress will be elusive. It is therefore necessary to look beyond internal peace to the emancipation of the entire Africa from the clogs of war and disunity. A very important tool for this pursuit is the use of language. The comment above shows the state of an average African who is afraid and suspicious of other Africans. The context of this discourse is provided by the news headline posted by Premium Times quoting Cyril Ramaphosa, the South Africa President and the newly elected Chairperson of African Union. The ideological polarity of the first comment tilts towards negative out-group against the west and the AU as an enabling tool in their hand. Furthermore, the discussion indicates that there has been unrest in some African countries which require the attention of the AU. Africans believe that the west has a role to play in the unrest in Africa. Africans want this addressed. 
NNAMDI AZIKIWE UNIVERSITY Journal of COMMUNICATION AND MEDIA STUDIES

Volume 1 Number 1 Maiden Issue

\section{Text 4}

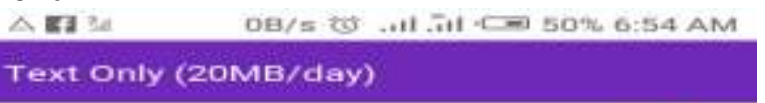

(ש) Premium Times

2023: North Elders Forum states condition to support candidate

He said: "The forum has observed that political manoeuvres around the 2023 elections are targeting the North as a region avallable for exploitati... Sere Mare

[E]

Photos shown when you have data

See All Links

2023: North Elders Forum states condition to support candidate

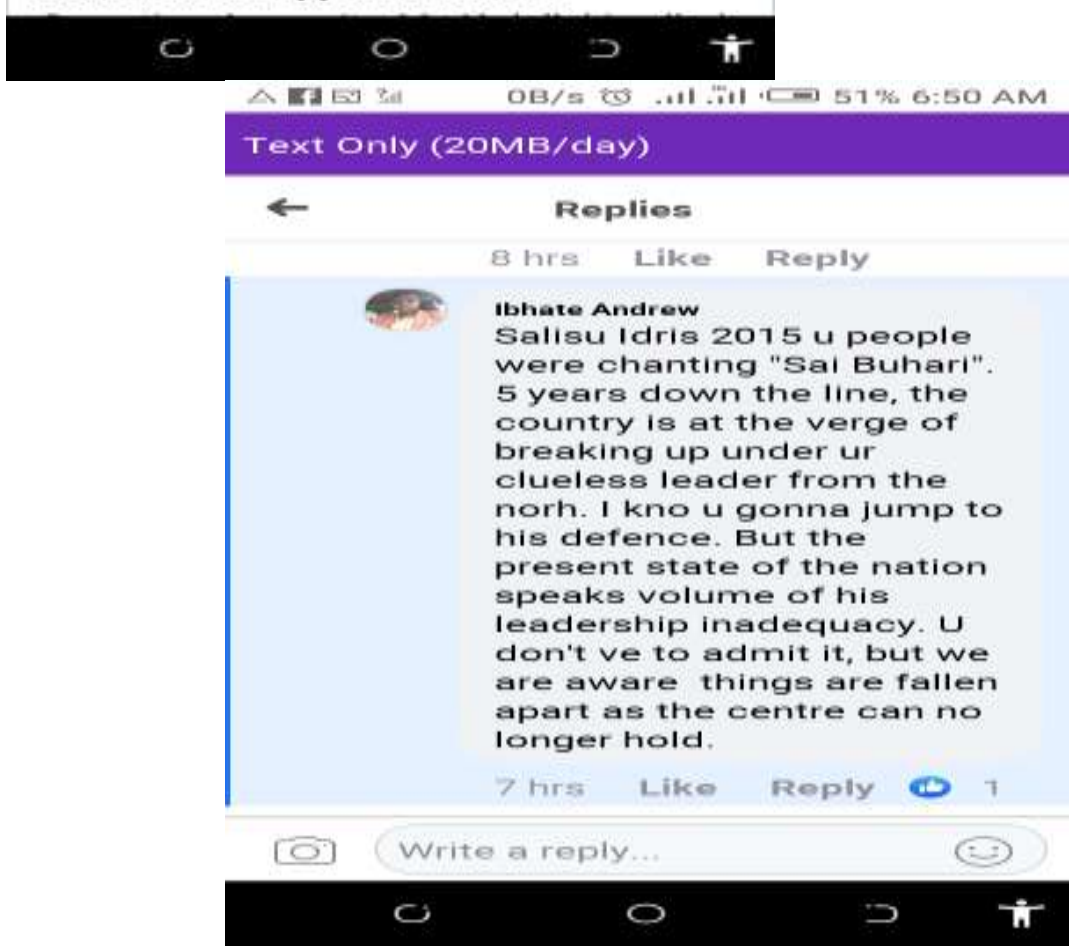




\begin{tabular}{|l|l|}
\hline Setting & Premium Times Newspaper on Facebook \\
\hline Participants & Ibhate Andrew \\
\hline Ends & $\begin{array}{l}\text { The comment is used to basically show utter rejection of the leadership } \\
\text { prowess of the present administration led by a northern president. His comment } \\
\text { demeans the capacity of President Muhammadu Buhari in stemming the tide of } \\
\text { security in the nation and fostering unity among the different ethnic } \\
\text { nationalities in the nation. This kind of comment is a common place on } \\
\text { Facebook. }\end{array}$ \\
\hline Acts Sequence & $\begin{array}{l}\text { The act of stating by the news medium is followed by adjacency sequence of } \\
\text { responding with demeaning the leadership ability of the president which in his } \\
\text { own opinion has failed in uniting the nation. }\end{array}$ \\
\hline Key & $\begin{array}{l}\text { This comment does not look like a joke as the tone is serious and it expresses } \\
\text { the general feel of the prevailing situation in the nation. }\end{array}$ \\
\hline Instruments & $\begin{array}{l}\text { The participant has deployed both English language and Pidgin English in } \\
\text { responding to the headline and the thread. }\end{array}$ \\
\hline $\begin{array}{l}\text { Norm of } \\
\text { Interaction }\end{array}$ & Turn-taking \\
\hline Genre & Short Facebook post. \\
\hline
\end{tabular}

\section{DISCUSSION}

Ideological thoughts are function of varying factors, but quite strongly is the exposures to ethnic predilections that have shaped the world view of people. The expression of these ideologies is also predetermined by cognitively enshrined personal tendencies which are contextualised within a society. The comment to the headline above shows the stance of the writer on the political and leadership prowess of a government led by a northern leader. Many people from the west hold an ideology about people from the north. It is this general perception that has played out in this comment. While it is quite clear that such comments may be largely unverifiable because of the chaotic and uncanny proclivities of some members of that ethnic extraction, it cannot therefore be correct to say such hegemonic comment.

This disquisition is not in any way in defence of the Buhari led government, but is it a modest attempt to show that language has a way of x-raying the ideological structure of a people. Very importantly also, the comment brings the other user back the memory lane when Gen. Muhammadu Buhari was the APC candidate, there was clearly a clamour for a change of government from every part of the country, but that clamour brought an elusive hope which has made many people critical of this administration. It is on that basis that this discourse was birthed. The comment by Ibhate Andrew shows that he did not first see Buhari as a Nigerian, but rather as a "clueless leader from the north", on the polarity scale, there is an out-group negative representation of the north and Buhari and implicitly, there is an in-group praise of his affiliation even though unstated. With this kind of clear polarity of discourse, attaining a pan-Nigerianism cannot be achieved. 


\section{Text 5}

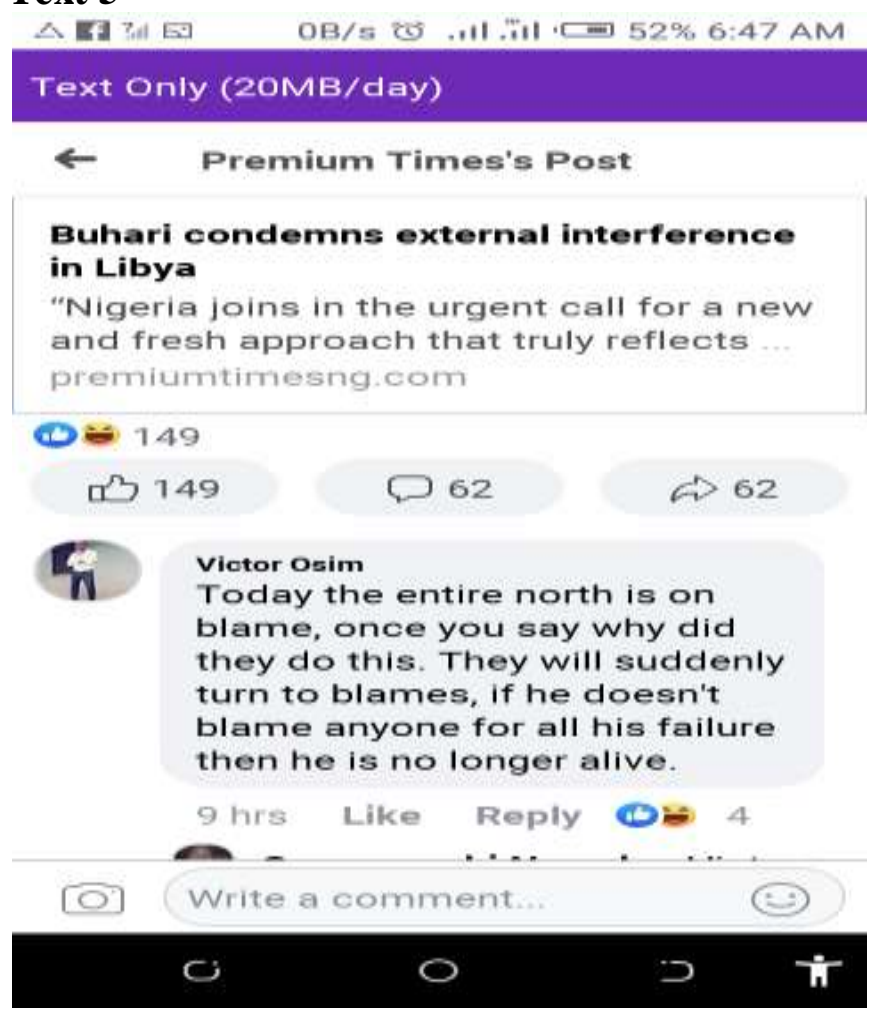

\begin{tabular}{|c|c|}
\hline Setting & Premium Times Newspaper on Facebook \\
\hline Participants & Victor Osim \\
\hline Ends & $\begin{array}{l}\text { The comment is used to show that Buhari has always blamed others for his } \\
\text { failures. }\end{array}$ \\
\hline Acts Sequence & $\begin{array}{l}\text { The expressive illocutionary act of condemning external interference in the } \\
\text { Libya crisis expressed by Buhari is followed by a comment that changes the } \\
\text { theme of the discourse of the Crisis in Libya to the person of President } \\
\text { Muhammadu Buhari. The act of indicting Buhari of always blaming others for } \\
\text { everything negative that happens around them is evident. }\end{array}$ \\
\hline Key & $\begin{array}{l}\text { It is clear that the comment is beyond mere Facebook tantrums. The comment } \\
\text { reflects a non-acceptance of the Buhari blame-game that has pervaded the } \\
\text { administration defence for their failings. It shows that people who have } \\
\text { followed the administration hold the belief that the administration has refused } \\
\text { consistently to take responsibility for their actions, inactions and even } \\
\text { reactions. }\end{array}$ \\
\hline Instruments & The commenting was posted in English language. \\
\hline $\begin{array}{l}\text { Norm of } \\
\text { Interaction }\end{array}$ & Turn-taking and synchronous \\
\hline Genre & Facebook post \\
\hline
\end{tabular}




\section{DISCUSSION}

The socio-political background of this text points to how the APC government has consistently blamed the previous administrations of their failure on certain fronts. This blame game has not stopped to play out in every slightest opportunity. This background provides the context for this comment. The writer holds the ideology that the president always blame somebody for certain things. The headline reveals how "Buhari condemns external interference in Libya", the writer from the comment deduced that the president is shifting the bulk of the crises in Libya to interference from some quarters. Because of this statement by President Buhari, Victor Osim whose identity is clear says "Today the entire north is on blame, once you say why they did this; they will suddenly turn to blames". His response to the headline is springing forth from a deep seated ideology and the beliefs about the north. The President Buhari's remark about the situation in Libya should not be the alibi for any Nigerian to make such vituperative comments about the north. The comment by the Facebook user shows President Buhari and the north in a negative out-group polarity. This shows a society that has consistently refused to be unified; the sentiment that is being entrenched cuts across the different ethnic nationalities of the country.

\section{CONCLUSION}

Language remains a cogent tool for creating and destroying. Language can be used as a fruitful tool for fostering unity among a seemingly divided people and it can be used to separate people. The use of language on Facebook has shown a conceptually divided people staying together in the same geographical location - Nigeria and Africa. The comments of people on issues indicate that while the concerns are legitimate and genuine, the use of language needs to be checked as it reflects an appalling situation. This kind of language use is capable of escalating the already tensed polity and the situation can degenerate into crisis. This study therefore submits that as a nation we must develop a collective sense of tolerance. Great nations are built on the things they have collectively agreed to love about themselves and the things they have agreed to hate about themselves. For peace to reign in Nigeria and in Africa, we need to employ the use of language that shows collective acceptance of the different ethnic groups across the continent. We must conceptually disabuse our cognitive process about the idea of "THEY". It must change to "WE". We recognise the role of Government in this process, but language planning and media literacy are intrinsic.

\section{REFERENCES}

Adedimeji, M. A. (2010). "A Stylo-Pragmatic Study of Proverbs in Selected Nigerian Novels in English." A PhD Thesis Submitted to the Department of English, Faculty of Arts, University of Ilorin

Ashcroft B. (2001). Language and Race. London: Routledge

Crystal, D. and D. Davy (1969). Investigating English Style, London: Longman

Chilton, P. and Schaffner, C. (1997) "Discourse and Politics", In Discourse as Social Interaction. Discourse Studies: A Multidisciplinary Introduction. London: Sage Publication. 2: 204-230. 
Etsu, A. (2019). Communicative Goals and Pragmatic Acts of Verbal Assaults in Selected Political Campaigns of 2015 General Elections. A Master's Dissertation in the Department of English, Ibrahim Badamasis Babangida University, Lapai, Niger State.

Fairclough, N. (1999). Critical discourse analysis: The critical study of language. United

Kingdom: Longman

Fairclough, N. (2001). Language and power. ( $\left.2^{\text {nd }} \mathrm{ed}\right)$. London: Longman

Halliday, M. A. K. (2004). An Introduction to Functional Grammar. Second Edition. London : Edward Arnold.

Hymes, D. (1964). 'Towards ethnography of communication events' in (ed) P.P. Giglioli (1972). Language and social context. Harmondsworth, Middx: Penguin Books

Mirzaee, S. and Hadi, H. (2012). Critical discourse analysis and Fairclough's model. International electronic journal for the teachers of English, 2(5), 2230-9136.

Ogungbe, E. O. (2008) “Critical Language Awareness and Nation-Building: A Critical Discourse Analysis of Representations of Governors of Northern States of Nigeria in Daily Trust's Text Us on 08050564331, 08023130396”. In Okegbile, A. S., Apara, S. A. E., Ogungbe, E. O., Talla, N. S. and Mohammed, M. H. (Eds), Education and Development in Northern Nigeria. Lapai: IBBUL

Taiwo, R. 2004. Speech as headline in Nigerian newspapers in S.Awonusi \& E.A Babalola (Eds.) The domestication of English in Nigeria (pp. 323-335). Lagos: University of Lagos press

Van Dijk, T. A. (1993). Principles of critical discourse analysis. Discourse \& Society, 4 (2), 249- 283

Van Dijk, T.A. (1998). Ideology: A Multidisciplinary Approach. London: Sage

Van Dijk, T.A. (2004). Politics, ideology and discourse. In Wodak, R (Ed) Encyclopedia of Language and Politics.. Second version

Van Dijk, T.A. (2008b). Discourse and Power. Basingstoke and New York: Palgrave Macmillan

Van Leeuwen, T. (1996). The representation of social actors. In Caldas-Couthard, C.R. and Coulthard, M. (eds). Readings in critical discourse analysis. London and New York: Routledge 32-70.

Wodak, R. (2000). Recontextualisation and the transformation of meaning: a critical discourse analysis of decision making in Eu-meetings about employment policies. In Sarangi, S. and Coulthard, M. (eds). Discourse and social life. Harlow: Pearson Educational. 185-206. 